\title{
Case Studies in Revenge: Philomel Gives Advice
}

Trust me on this.

It turns to ash in your mouth.

(The cold air glitters above me.

I know what I know.

I've tasted blood.)

Like this one guy I knew who was in love with this girla tiny, 90-pound thing who was always getting beaten up by her boyfriend, who was seven years older and huge. So one night this guy (maybe sixteen, ghost-white, only 140 pounds) waits outside the bar where the boyfriend works

as a bouncer.

He pulls the boyfriend into an alley, pushes him to the ground, stands over him with a metal bat. Tells him he should kill him. The boyfriend starts to cry and the guy thinks, "Pathetic." He still wants to kill him but won't. The boyfriend pleads, promises he won't touch her again. The girl later complains to this same guy that her boyfriend won't return her calls.

(The glint from empty beer cans still stacked on her dresser.)

And this other girl I know, there was a boy who picked on her in school, called her names because her mom shopped at the wrong stores, 
she ate lunch with the wrong people,

had the wrong accent, etc.

She hated him and prayed

he would die. Two years later

he gets thrown through a windshield.

His best friend got leukemia.

She alone survives. Now she's afraid to hate,

but dresses impeccably.

(She grips the steering wheel with white, white hands.)

And this other woman

she married young (in a white minidress

she holds white roses) a man

who bullied her, threw chairs at her

and she lived with it eleven years

and swore when her children were older

she would leave him. But then she fell

in love with him again

(his guitar music, his desire for only white cars)

and stayed another eleven years.

Her kids say she's nuts.

When I had my fill

of revenge, I began

making music. It tasted sweeter.

(The air's edge like a knife in my feathers.) 